\title{
Money Supply and Inflation: Disaggregated Time Series Evidence from Nigeria
}

\author{
Nwonodi Daniel Ikezam ${ }^{1}$ \\ ${ }^{1}$ Department of Banking and Finance, Rivers State University, Port Harcourt, Nigeria, Nigeria. \\ Correspondence: Department of Banking and Finance, Rivers State University, Port Harcourt, Nigeria, Nigeria
}

Received: January 20, 2018

Accepted: January 26, 2018

Online Published: February 7, 2018

\section{Abstract}

This paper examined money supply and inflation in Nigeria. The objective was to examine the extent to which components of money supply affect Nigerian inflation rate. Time series data was sourced from Central Bank of Nigeria $(\mathrm{CBN})$ statistical bulletin and Stock Exchange Factbook. Nigerian Real Inflation Rate was proxy for dependent (INFR) variables while Currency in Circulation (CR), Demand Deposit (DD), Time Deposit (TD), Savings Deposit (SD) and Net Foreign Asset (NFA) were used as independent variables. The Ordinary Least Square (OLS) method of cointegration, Augmented Dickey Fuller Unit Root, Granger Causality was used as data analysis techniques. Regression result in the study shows that Currency in Circulation, Demand Deposit and Savings Deposit has negative relationship while Net Foreign Asset and Time Deposit have positive relationship with inflation. The Augmented Dickey Fuller Test proved non stationarity of the variables at level except Net Foreign Asset but stationary at first difference. The Granger Causality Test reveals no casual relationship running through the variables. The cointegration proved no long run relationship between the dependent and independent variables. The study conclude that Money Supply have significant relationship with Nigerian Inflation Rate. It therefore recommends effective management of money supply by the monetary authorities to achieve the monetary policy objectives of price stability.

Keywords: Money Supply, Inflation, Currency in Circulation, Demand Deposit, Saving Deposit.

\section{Introduction}

Money supply is an instrument of monetary authorities used to fine-tune the economy to achieve desired macroeconomic goals. In Nigeria, Central Bank of Nigeria Decree 1969 as amended empowered CBN the monetary function of regulating the volume of money in circulation which is influenced by the economic condition, when the economy is inflationary the monetary authority reduces money supply to achieve price stability. However, when the economy is depressed, the monetary authorities increase the decline of money in circulation. This process is the socalled expansionary and contractionary monetary policy. From the classical perspective, inflation is a monetary issue and can only be controlled by reduction in monetary circulation.

Inflation remains one of the major economic variables that can distort economic activities in both develop and less develop countries. Although it has been argued that moderately rising prices (single digit inflation) initially activates the level of economic activities (Adeoye 2002), continuous inflation however, is evil to any economy. At the microlevel, it arbitrarily redistributes income, wipes out savings, erodes real income (fixed income earners), leads to price distortions and it brings about misallocation of economic resources at the aggregate level (Adeoye 2002). Thus, understanding the factors driving inflation is very vital for the formulation and implementation of appropriate macroeconomic policies.

The monetarist led by Milton Friedman believes that inflation is always and everywhere a monetary phenomenon. The argument on factors that determines inflation has long been examined and dates back to the divergences between the classical and the Keynesians economist. This argument has been deepened in a developing economy like Nigeria where the financial market is emerging and cannot absorb the financial contagion of the economic units. For instance, an empirical examination of Nigerian savings reveals that significant proportion of money supply is outside the banking system. This means there is excess money in circulation which is sensitive to inflation. Again, there is also mis-match of monetary policy with fiscal policy in the developing country like Nigeria, for instance 
monetary policy can be contractionary while fiscal policy can be expansionary. The divergences between the two schools of thought have attracted academic attentions. From the above, this study intends to examine the relationship between money supply and Nigerian inflation rate.

\section{Literature Review}

\subsection{Theoretical Framework}

The monetarists, following from the Quantity Theory of Money (QTM), have propounded that the quantity of money is the main determinant of the price level, or the value of money, such that any change in the quantity of money produces an exactly direct and proportionate change in the price level. The QTM is traceable to Irving Fishers famous equation of exchange: $\mathrm{MV}=\mathrm{PQ}$, where $\mathrm{M}$ stands for the stock of money; $\mathrm{V}$ for velocity of circulation of money; Q is the volume of transactions which take place within the given period; while $\mathrm{P}$ stands for the general price level in the economy. Transforming the equation by substituting $Y$ (total amount of goods and services exchanged for money) for $\mathrm{Q}$, the equation of exchange becomes: $\mathrm{MV}=\mathrm{PY}$. The introduction of $\mathrm{Y}$ provides the linkage between the monetary and the real side of the economy. In this framework, however, P, V, and Y are endogenously determined within the system. The variable $\mathrm{M}$ is the policy variable, which is exogenously determined by the monetary authorities.

The monetarists emphasized that any change in the quantity of money affects only the price level or the monetary side of the economy with the real sector of the economy totally insulated. This indicates that changes in the supply of money do not affect the real output of goods and services, but their values or the prices at which they are exchanged only. An essential feature of the monetarists' model is its focus on the long-run supply-side properties of the economy as opposed to short-run dynamics (Dornbush, et al, 1996).

The Keynesian opposed the monetarists' view of direct and proportional relationship between the quantity of money and prices. According to this school, the relationship between changes in the quantity of money and prices is nonproportional and indirect, through the rate of interest. The strength of the Keynesian theory is its integration of monetary theory on the one hand and the theory of output and employment through the rate of interest on the other hand. Thus, when the quantity of money increase, the rate of interest falls, leading to an increase in the volume of investment and aggregate demand, thereby raising output and employment. In other words, the Keynesians see a link between the real and the monetary sectors of the economy an economic phenomenon that describes equilibrium in the goods and money market (IS-LM). Equally important about the Keynesian theory is that they examined the relationship between the quantity of money and prices both under unemployment and full employment situations. Accordingly, so long as there is unemployment, output and employment will change in the same proportion as the quantity of money, but there will be no change in prices. At full employment, however, changes in the quantity of money will induce a proportional change in price. The neo-Keynesian theoretical exposition combines both aggregate demand and aggregate supply. It assumes a Keynesian view on the short-run and a classical view in the long-run.

The simplistic approach is to consider changes in public expenditure or the nominal money supply and assume that expected inflation is zero. As a result, aggregate demand increases with real money balances and, therefore, decreases with the price level. The neo-Keynesian theory focuses on productivity, because, declining productivity signals diminishing returns to scale and, consequently, induces inflationary pressures, resulting mainly from overheating of the economy and widening output gap. But by and large, the theories outlined above by various schools of thought in economics provide a better understanding of the position of inflation as a macroeconomic variable in the mainstream economic thought and its effect on the overall performance of the economy. Among all the theories, the monetarist theory is adopted because its proposition fairly satisfied the realities of the projected causes of inflationary pressure in Nigeria.

2.2 Empirical Literature

Omoke et, al,(2010) tested the causal long term relationship between budget deficit, money growth and inflation in Nigeria and the result of the study pointed to a close long term relationship between inflation and money supply. Another important issue arising from the foregoing is the link between inflation on one hand and market interest rate on the other. Perceptual inflation generates expectations about the cause of factored prices and puts on upward bias on market interest rates as lenders seek to protect the real value of their funds. It is important to point out that the long term positive effect of money stock changes on output is generally considered to be tenuous. Thus, the main long term effect of excessive money stock growth appears to be negative, that is a sustained rise in the price level. Long term growth is generally considered to depend on real factors such as resources endowments, technology, and high productivity and inter- temporal choices between present and future consumption. 
Nwaobi (2002) used data from 1960 through 1995 and the Johansen co-integration framework found that money demand, real GDP, inflation and interest rate are co integrated in Nigeria. He also found stable money demand in the period under study.

Fatukasi (2004) investigated the determinants of inflation in Nigeria between 1981 and 2003. The study made use of non-linear multiple regression models. He posited that the causes of inflation in Nigeria are multi-dimensional and dynamic, requiring full knowledge at any point in time to be able to proffer solutions to the inflationary trends in the country.

Omokeet et al., (2010) tested the causal long-term relationship between budget deficit, money growth and inflation in Nigeria. Augmented Dickey-Fuller (ADF) and Philip-Perron (PP) test were carried out to test the stationarity of the variables used. The result of the study pointed to a close long-term relationship between inflation and money supply.

Olusanya (2009) analyzed the main sources of fluctuations in inflation in Nigeria. Using the framework of error correction mechanism (ECM) it was found that the lagged CPI, expected inflation, petroleum prices and real exchange rate significantly propagate the dynamics of inflationary process in Nigeria.

Bakare (2011) conducted a study on the determinants of money supply growth and its implications on inflation in Nigeria. The study employed quasi-experimental research design approach. The results showed that credit expansion to the private sector determines money supply growth and inflation in Nigeria. He therefore concluded that changes in money supply are concomitant to inflation in Nigeria.

Marta et al. (2004), examines monetary policy in Albania during the transition period. Estimates from a vector Auto Regression Model (VAR) of key macroeconomic variables which include money growth, inflation, exchange rate, remittances and the trade balance, demonstrate the weak link between money supply and inflation up to mid 2000. They conclude that exchange rate stability has played a key role in keeping inflation low for most of the transition period, and that the range of monetary policy instruments available to the authorities has widened in recent years and this has been associated with more stable and predictable changes in money supply and the price level. The result demonstrates that Albania has come a long way in terms of controlling inflation, liberalizing Akinbobola financial markets and improving the predictability of inter-relations among key macroeconomic variables.

Holod (2000) explores the identified vector autoregression to model the relationship between CPI, money supply and exchange rate in Ukraine. The results show that exchange rate shocks significantly influence price level behaviour. Further, the study also found that money supply responds to positive shocks in price level. The study contributes to the sizable literature on IT using overly sophisticated vector error correction model with complex identification structure. There is however an element of data mining in the generation of impulse response functions. Nicolleta and Edward (2001), updates and extends Friedman's (1972) evidence on the lag between monetary policy actions and the response of inflation. Their evidence is based on UK and US data for the period 1953-2001 on money growth rates, inflation and interest rates, as well as annual data on money growth and inflation. Their findings reaffirm the result that it takes over a year before monetary policy actions have their peak effect on inflation.

Novoseletska (2004) discussed this issues taking note of the break point in the statistical relationship. In a more recent period of financial stability (1999-2003) rising monetary aggregate were accompanied by falling inflation and a rebound of output. Novoseletska and Myhaylychenko (2004), note that nominal exchange rate stability could contribute to moderate growth rates of prices during the last few years.

Clemens and Alex (2002) empirically estimated and tested the relationship between exchange rate accommodation and the degree of inflation persistence using a non-linear autoregressive inflation equation for ten European countries for the period 1974 to 1998. In the estimation procedure they allow for the presence of an unknown number of shifts in the mean of inflation. Their results provide supportive evidence for the existence of a positive link between exchange rate accommodation and inflation persistence for most of the smaller and more dependent exchange rate mechanism (ERM) countries, even when mean level shifts in inflation are appropriately accounted for. For the larger countries and the countries that remained outside the ERM for most of the period they find hardly any evidence of such positive link. Overall, their results provide modest support for the existence of the theoretically hypothesized positive link between exchange rate accommodation and inflation persistence.

Bleaney (2000) implicitly recognizes that at least two problems arise from the literature. First, the identification of periods within which persistence is constant using the prevailing exchange rate regime is generally inappropriate. The dynamics of money supply, exchange rate and inflation in Nigeria variation in persistence within constant regime periods to independent changes in the main level of inflation, which is questionable as well.

Bernhardsen and Holmsen (2005) discussed whether inflation forecasts should be based on technical exchange rate assumptions like a constant exchange rate and uncovered interest rate parity (UIP) or on assumptions reflecting the 
central bank's best prediction of future exchange rate movements. Because of the strong link between the interest rate and the exchange rate, the exchange rate does not principally differ from other variables that are endogenous in inflation projections.

Debelle and Galati (2005) argued that along with changes in output growth, exchange rate changes have historically played a key role in the adjustment of external imbalances in industrial countries. Zettelmeyer (2004), and Kearns and Manners (2005) finds that, a surprise monetary policy shock that increases the interest rate has a significant appreciating effect on the exchange rate. As Frankel (1999) observes, fixing the exchange rate has the advantage of providing an observable commitment to monetary policy.

Atkenson and Kehoe (2001) believed that fixing the exchange rate has the advantage of providing an observable commitment to monetary policy. They formalize the argument that because it is more transparent, the exchange rate has a natural advantage as an instrument for monetary policy.

Bleaney (2001) asserts that there has been stronger monetary policy response to inflation shocks in recent decades. He finds that monetary growth in the United.Mahamadu and Philip (2003) explore the relationship between monetary growth, exchange rates and inflation in Ghana using Error Correcting Mechanism. The empirical result confirms the existence of a long run equilibrium relationship between inflation, money supply, exchange rate and real income. In line with theory, the findings demonstrate that in the long-run, inflation in Ghana is positively related to the money supply and the exchange rate, while it is negatively related to real income. Elsewhere, several authors have been pre-occupied with the factors determining inflation, especially in the last few years.

Canetti and Greene (2000) separated the influence of monetary growth from exchange rate changes on prevailing and predicted rates of inflation. The sample covers ten African countries: The Gambia, Ghana, Kenya, Nigeria, Sierra-leone, Somalia, Tanzania, Uganda, Zaire, and Zambia. Using the Vector auto regression analysis, they suggest that monetary dynamics dominate inflation levels in four countries, while in three countries; exchange rate depreciations are the dominant factor.

Rutasitara (2004) investigates the influence of exchange rates on inflation in Tanzania. Model estimation lend support to the structural view of inflation and show a high degree of persistence as the current rate reflects about 0.6 of its value four quarters back. The study contributes to the debate on the controversies about the relative role of exchange rates in discussion of Structural Adjustment Programmes (SAP) and stabilization policies.

Bozkurt (2014) examines money, inflation and growth relationship in Turkey by using co-integration test. For this purpose, quarterly data of money supply (M2), GDP, velocity of money and deflator are used for the period of 1999:2 - 2012. According to the results from this paper, money supply and velocity of money are the main determinants of inflation in the long run in Turkey. On the other hand, $1 \%$ decreases in income directly reduces inflation by $1 \%$.

Koyuncu (2014) uses the time-series approach to investigate the impact of budget deficit and money supply on inflation in Turkey for the period of 1987-2013. He finds that while there is no causality from inflation to money supply, there is causality from money supply to inflation in Turkey.

Al-Fawwaz and Al-Sawai'e (2012) analyze the short run relationship between money, the price, and the gross domestic product (GDP) growth for the Jordanian economy. Time series methods are used for the annual data for the period 1976-2009. The result indicates that there is a causal relationship from money supply to inflation, with low degree of 0.21 .

Mbongo, Mutasa and Msigwa (2014) examine the effects of money supply on inflation in Tanzania. The study applies OLS, VAR and ECM techniques to examine the effect of selected variables on inflation in Tanzania. OLS and ECM results show that money supply and exchange rate have significant impact on inflation in the short and long run. The VAR findings indicate that the current inflation can be influenced by the past state inflation.

Abate and Nandeeswara (2015) show the causality effect between money supply growth and price level in Ethiopia using a co-integrated vector auto regressive (VAR) model over the period 1975 to 2012. To explore the short-run direction of causality between money supply and consumer price index (CPI), Granger causality test has been applied and in order to investigate the existence of long-run relationship, co-integration analysis has been employed. The causation runs from money supply to prices, but price level does not causes money supply. The co- integration analysis established that money supply and CPI are found to be co-integrated suggesting an existence of long-run relationship.

Ahmed and Suliman (2011) examined the long-run relationships between real gross domestic product (GDP), money supply (MS) and price level (CPI)) for the Sudan economy using annual data for the period of 1960 to 2005. To explore the short-run direction of causality between GDP, MS and CPI, Granger causality test has been applied and in order to investigate the existence of long-run relationship, co-integration analysis has been employed. The causation runs from money supply to prices, but price level does not causes money supply. The co-integration 
analysis established that the real GDP, money supply and CPI are found to be co integrated suggesting an existence of long-run relationship.

Mbutor (2014) determines the exact portion of the changes that occur in aggregate prices that could be attributed exclusively to the growth in money supply in Nigeria for the period of 1970 to 2012 . The gross domestic product, nominal exchange rate, and the maximum lending rate are control variables, while inflation, proxy by the consumer price index and broad money supply are focus variables. All variables enter in logarithm forms, except interest rate. The impulse response function shows a persistent positive relationship between inflation and money supply. The variance decomposition of inflation shows that money supply accounts for up to 34.5 percent of aggregate price changes until the tenth period.

Olorunfemi and Adeleke (2013) examine money supply and inflation rate in Nigeria for the period of 1970-2008. The study uses vector auto regressive (VAR) model. Results from the causality test indicate that there exists a unidirectional causality between money supply and inflation rate. The causality test runs from money supply to inflation.

Umeora (2010) examines the effects of money supply (M2) and exchange rates on inflation in Nigeria for the period of 1982 to 2009 using annual data. The data are analyzed using multiple regression analysis (with SPSS). The results show that money supply and exchange rate have positive and negative effects on inflation in Nigeria respectively. The two variables account for only about $12 \%$ of the variation of inflation in Nigeria.

Odiba, Apeh and Daniel (2013) investigate the effect of money supply and aggregate demand on inflation in Nigeria for the period of 1986-2009. The data are analyzed using ordinary least square regression. The results show that money supply and aggregate demand are the main determinants of inflation in Nigeria during the review period.

Akinbobola (2012) aims at providing quantitative analysis of the dynamics of money supply, exchange rate and inflation in Nigeria. The sample covers quarterly data from 1986:01 to 100 Mathias A. Chuba: Transmission Mechanism from Money Supply to Inflation in Nigeria 2008. The model was estimated using vector error correction mechanism (VECM). The empirical results show that in the long run, money supply and exchange rate have significant inverse effects on inflationary pressure in Nigeria.

Omanukwe (2010) examines the modern quantity theory of money using quarterly time series data in Nigeria for the period 1990:1-2008:4. The Granger causality is used to examine the causality between money and prices. The result shows the weak unidirectional causality from money supply to core consumer prices in Nigeria.

Adesoye (2012) examines the co-integration causality between prices, monetary aggregate and real output in Nigeria from the period 1970 to 2009 using the inflationary gap model that emanates from the quantity theory of money. The causality is found to significantly run from money supply to price. The econometric findings suggest that inflation in Nigeria is a monetary phenomenon.

Yahya (2000) concluded in his work that despite the distorting effects of a civil war followed by an oil commodity boom and burst, Nigeria's inflationary experience could be traced ultimately to excessive monetary growth. The dynamics of money supply, exchange rate and inflation in Nigeria macroeconomic accounting framework, he developed a framework for analyzing Nigeria's inflationary experience, and found that any adjustment policy that does not take into account the role of money and credit is likely to fall short of the overall goal of non-inflationary economic growth.

Odusola and Akinlo (2001) examined the link between the naira depreciation, inflation and output in Nigeria, adopting Vector Autoregression (VAR) and its structural variant. Their results tend to suggest that the adoption of flexible exchange rate system does not necessarily lead to output expansion, particularly in the short-term. Issues such as discipline, confidence and credibility on the part of the government (as argued by Dordunoo and Njinkeu, 1997) are essential. Evidence from impulse response functions and structural VAR models suggested that the impacts of the lending rate and inflation on the output were negative. While most previous studies focus more on the determinants of inflation, using explanatory variables, ours deviates by adopting the Vector Error Correction Mechanism (VECM) which eliminates the need to develop explicit economic models and thus impose apriori restrictions on the relationships among variables, VECM analysis permits a more general test of causation among different economic variables than is possible in conventional econometric analysis.

3. Research Methodology

This study intends to examine the impact of money supply on inflation rate in nigeria. The relevant data was sourced from Central Bank of Nigerian Statistical Bulletin. Time series data were used and econometric method of data analyses which involves Ordinary Least Square (OLS) were employed. The multiple regressions formulated in this study is based on the theory of money supply and inflation rate.

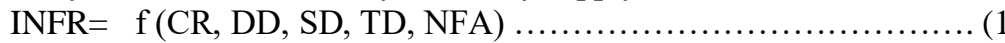

Transforming equation 1 above to econometric method, we have: 


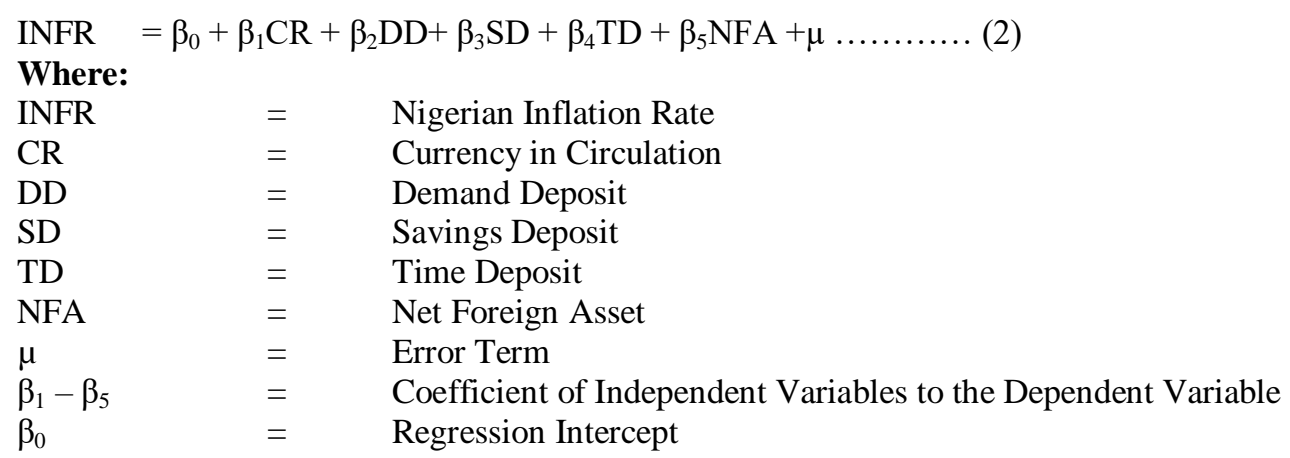

\subsection{Estimation Techniques}

\subsubsection{Stationarity Test}

Time series data are assumed to be non-stationary and this implies that the result obtained from Ordinary Least Square (OLS) may be misleading (Suleman and Azeeze, 2012). It is therefore necessary to test the stationarity of the variables using the Augmented Dickey Fuller 1979 test to both level and first difference. The ADF test constructs a parameter correction for higher order correlation by assuming the times series follows an auto regressive process. Mathematically expressed as

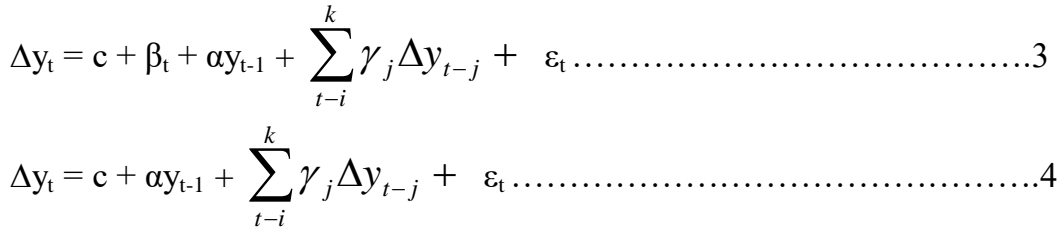

Equation 1 is used to test for the null hypotheses of non stationarity of unit root against trend stationaerity alternative in $\mathrm{Y}_{\mathrm{t}}$ where $\mathrm{y}$ refers to the examined time series. Equation 2 tests the null hypotheses of a unit root against a mean stationarity alternative.

3.1.2 Johansen Cointegration Test

The cointegration test established whether a long run equilibrium relationship exist among the variables. It is generally accepted that to establish a cointegration, the likelihood ratio must be greater than the Mackinnon critical values. The model can be stated as

$$
\Delta X_{t}=\mu+\Psi_{1} \Delta X_{t-1}+\Psi_{2} \Delta X_{t 2}+\ldots+\Psi_{p-1} \Delta X_{t}-p+1 \ldots \ldots \ldots . .5
$$

Where $\mu$ is a constant term.

$\Delta X_{t}$ Represents the first cointegrating differences

\subsubsection{Granger Causality}

To determine the direction of causality between the variables, the study employed the standard Granger causality test (Granger, 1969). The test is based on Vector Error Correction Model (VECM) which suggests that while the past can cause or predict the future, the future cannot predict or cause the past. Thus, according to Granger (1969) X Granger cause $\mathrm{Y}$ if past value of $\mathrm{X}$ can be used to the past value of $\mathrm{Y}$, the test is based on the following regression model.

$$
\begin{aligned}
& I N F R=\alpha_{2 t}+\sum_{j=1}^{k} \phi_{2 j} C R_{t-j}+\sum_{j=1}^{k} \beta_{2 j} D D_{1-j}+\sum_{j=1}^{k} \lambda_{2 j} S D_{t-j}+\sum_{j=1}^{k} \theta_{2 j} T D_{t-j}+\sum_{j=1}^{k} \delta_{2 j} N F A_{t-j}+\mu \\
& C R=\alpha_{2 t}+\sum_{j=1}^{k} \phi_{2 j} I N F R_{t-j}+\sum_{j=1}^{k} \beta_{2 j} D D_{1-j}+\sum_{j=1}^{k} \lambda_{2 j} S D_{t-j}+\sum_{j=1}^{k} \theta_{2 j} T D_{t-j}+\sum_{j=1}^{k} \delta_{2 j} N F A_{t-j}+\mu . \\
& D D=\alpha_{2 t}+\sum_{j=1}^{k} \phi_{2 j} I N F R_{t-j}+\sum_{j=1}^{k} \beta_{2 j} C R_{1-j}+\sum_{j=1}^{k} \lambda_{2 j} S D_{t-j}+\sum_{j=1}^{k} \theta_{2 j} T D_{t-j}+\sum_{j=1}^{k} \delta_{2 j} N F A_{t-j}+\mu \\
& S D=\alpha_{2 t}+\sum_{j=1}^{k} \phi_{2 j} I N F R_{t-j}+\sum_{j=1}^{k} \beta C R_{2 j}+\sum_{j=1}^{k} \lambda_{2 j} D D_{t-j}+\sum_{j=1}^{k} \theta_{2 j} T D_{t-j}+\sum_{j=1}^{k} \delta_{2 j} N F A_{t-j}+\mu
\end{aligned}
$$

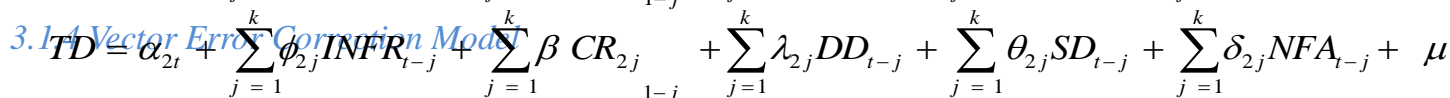

$$
\begin{aligned}
& N F A=\alpha_{2 t}+\sum_{j=1}^{k} \phi_{2 j} I N F R_{t-j}+\sum_{j=1}^{k} \beta C R_{2 j}+\sum_{j=1}^{k} \lambda_{2 j}^{59} D D_{t-j}+\sum_{j=1}^{k} \theta_{2 j} S D_{t-j}+\sum_{j=1}^{k} \delta_{2 j} T D_{t-j}+\mu
\end{aligned}
$$


Co-integration is a prerequisite for the error correction mechanism. Since co-integration has been established, it is pertinent to proceed to the error correction model. The VECM is of this form:

$$
\Delta y_{t}=\alpha \beta y_{t-1}+\sum_{i=1}^{j=1} \Gamma_{j} \Delta y_{t-1}+\pi+\varsigma_{t}, t=1, \ldots \ldots, T
$$

Where $Y_{t}$ is a vector of indigenous variables in the model. $\alpha$ is the parameter which measures the speed of adjustment through which the variables adjust to the long run values and the $\beta$ is the vectors which estimates the long run cointegrating relationship among the variables in the model. $\pi$ is the draft parameter and is the matrix of the parameters associated with the exogenous variables and the stochastic error term.

4. Results and Discussion

To ascertain the dynamic relationship between the variable, the following tables gives an insight.

4.1 Presentation of OLS Results

Table 1: Regression Results

\begin{tabular}{|c|c|c|c|c|}
\hline Variable & Coefficient & T-Statistics & & \\
\hline INFR & -0.128869 & 0.157710 & -0.817125 & 0.4208 \\
\hline $\mathrm{CD}$ & -0.733564 & 0.711558 & -1.030926 & 0.3114 \\
\hline DD & -2.391441 & 0.957630 & -2.497250 & 0.0187 \\
\hline $\mathrm{SD}$ & 1.014112 & 0.746346 & 1.358769 & 0.1851 \\
\hline TD & 0.149095 & 0.119291 & 1.249841 & 0.2217 \\
\hline NFA & 97.13793 & 35.19558 & 2.759947 & 0.0101 \\
\hline$\beta_{0}$ & 0.128869 & 0.157710 & -0.817125 & 0.4208 \\
\hline $\mathrm{R}^{2}$ & 0.775921 & - & - & - \\
\hline ADJ R $^{2}$ & 0.646621 & - & - & - \\
\hline F-STATISTICS & 12.13390 & - & - & - \\
\hline PROB. F & 0.000653 & - & - & - \\
\hline D.W & 1.475208 & - & - & - \\
\hline
\end{tabular}

4.1.1 Discussion of Results

Source: Author's computation from E-view 7.0

The regression results presented in the above table reveal the relationship between the dependent and the independent variable as formulated in the regression model. The model summary proxy by $\mathrm{R}^{2}$ and adjusted $\mathrm{R}^{2}$ shows that $75.9 \%$ and $64.6 \%$ variation in Nigerian inflation rate is traceable to the component of money supply in the model. The F-statistics and the probability value of 12.933960 and probability of 0.000653 prove that the model is significant and fit to test the relationship between the dependent and the independent variables. The DurbinWatson statistics of 1.475208 is above 1.00 and less than 2.00 this shows that there is positive auto-correlation between the variables in the time series.

The regression co-efficient shows that currency in circulation, demand deposit and time deposit has negative relationship with inflation. This finding is contrary to the classical opinion of inflation as a linear function of money supply but validate the Keynesian's opinion that inflation is a linear function of deficiencies in components of aggregate demand. However, savings deposit and net foreign asset have positive relationship with Nigeria inflation rate. This finding is in line with the classical theory but contradict the Keynesians view. The probability value and the T-statistics shows that CR, DD and TD are statistically significant meaning that increase in the variable will significantly affect Nigerian inflation rate.

Table 2: Presentation of ADF Test at Level

\begin{tabular}{lllllll}
\hline Variable & ADF Statistics & \multicolumn{3}{c}{ Critical Values } & Prob. & Order of Integration \\
\cline { 3 - 6 } & & $\mathbf{1 \%}$ & $\mathbf{5 \%}$ & $\mathbf{1 0 \%}$ & & \\
\hline & & & & & & \\
\hline INFR & -3.259192 & -3.646342 & -2.954021 & -2.615817 & 0.0253 & $1(0)$ \\
\hline CR & -3.946979 & -3.653730 & -2.957110 & -2.617434 & 0.0048 & $1(0)$ \\
\hline DD & -2.395771 & -3.646342 & -2.954021 & -2.615817 & 0.1498 & $1(0)$ \\
\hline TD & -3.654719 & -3.646342 & -2.954021 & -2.615817 & 0.0098 & $1(0)$ \\
\hline SD & -3.430947 & -3.646342 & -2.954021 & -2.615817 & 0.0098 & $1(0)$ \\
\hline NFA & -5.050256 & -3.653730 & -2.957110 & -2.617434 & 0.0003 & $1(1)$ \\
\hline
\end{tabular}

Source: Author's computation from E-view 7.0 
The above table indicates that at level the variables are not stationary except Net Foreign Asset as the ADF critical values are greater than the Mackinnon Critical Values at 1\%, 5\% and 10\%. Therefore the null hypotheses of nonstationarity are accepted while the alternate rejected.

Table 3: ADF at First Difference

\begin{tabular}{lllllll}
\hline Variable & ADF Statistics & \multicolumn{3}{c}{ Critical Values } & Prob. & Order of Integration \\
\cline { 2 - 6 } & & $\mathbf{1 \%}$ & $\mathbf{5 \%}$ & $\mathbf{1 0 \%}$ & \\
\hline INFR & -5.730629 & -3.670170 & -2.963972 & -2.621007 & 0.0000 & $1(1)$ \\
\hline CR & -6.559663 & -3.670170 & -2.963972 & -2.621007 & 0.0000 & $1(1)$ \\
\hline DD & -6.081278 & -3.65370 & -2.957110 & -2.617434 & 0.0000 & $1(1)$ \\
\hline TD & -6.222737 & -3.661661 & -2.960411 & -2.619160 & 0.0000 & $1(1)$ \\
\hline SD & -5.822923 & -3.661661 & -2.960411 & -2.619160 & 0.0000 & $1(1)$ \\
\hline NFA & -6.816334 & -3.661661 & -2.960411 & -2.619160 & 0.0000 & $1(1)$ \\
\hline
\end{tabular}

Source: Author's computation from E-view 7.0

From the above, all the variables are stationary at first difference, this means the null hypothesis of non-stationarity is rejected and the alternate accepted.

Table 4: Granger Causality Test

\begin{tabular}{lccc}
\hline \hline Null Hypothesis: & Obs & F-Statistic & Prob. \\
\hline \hline CR does not Granger Cause INFR & 32 & 0.01574 & 0.9844 \\
\hline INFR does not Granger Cause CR & & 0.14977 & 0.8616 \\
\hline \hline DD does not Granger Cause INFR & 32 & 2.10282 & 0.1417 \\
\hline INFR does not Granger Cause DD & & 1.48405 & 0.2446 \\
\hline \hline TD does not Granger Cause INFR & 32 & 0.65479 & 0.5276 \\
\hline INFR does not Granger Cause TD & & 0.59059 & 0.5610 \\
\hline \hline SD does not Granger Cause INFR & 32 & 0.21831 & 0.8053 \\
\hline INFR does not Granger Cause SD & & 0.59035 & 0.5611 \\
\hline \hline NFA does not Granger Cause INFR & 32 & 1.94118 & 0.1630 \\
\hline INFR does not Granger Cause NFA & & 0.60173 & 0.5550 \\
\hline \hline
\end{tabular}

From the granger causality results presented above, the probability coefficient of the variables are greater than the critical 0.05 at $5 \%$ level of significant and $95 \%$ confidence level, thereof the research conclude that there is no causal relationship among the variables.0

Table 5: Cointegration Test Results (TRACETEST)

\begin{tabular}{lcccl}
\hline Hypothesis CE & Trace Statistics & 0.05 Critical Value & Probability & Remark \\
\hline $\mathrm{r}=0$ & 127.3628 & 95.75366 & 0.0001 & Reject $_{0}$ \\
\hline $\mathrm{r} \leq 1$ & 67.62563 & 69.81889 & 0.0739 & Accept $\mathrm{H}_{0}$ \\
\hline $\mathrm{r} \leq 2$ & 39.46516 & 47.85613 & 0.2422 & Accept $\mathrm{H}_{0}$ \\
\hline $\mathrm{r} \leq 3$ & 21.61151 & 29.79707 & 0.3206 & Accept $\mathrm{H}_{0}$ \\
\hline $\mathrm{r} \leq 4$ & 9.582501 & 15.49471 & 0.3142 & Accept $\mathrm{H}_{0}$ \\
\hline $\mathrm{r} \leq 5$ & 2.631519 & 3.841466 & 0.1048 & Accept $\mathrm{H}_{0}$ \\
\hline
\end{tabular}

Table 6: Cointegration Test (Maximum Eigen Value)

\begin{tabular}{lrrrl}
\hline Hypothesis & Maximum Eigen Value & 0.05 Critical Value & Probability & Remark \\
\hline $\mathrm{r}=0$ & 59.73715 & 40.07757 & 0.0001 & Reject $\mathrm{H}_{0}$ \\
\hline $\mathrm{r} \leq 1$ & 28.16047 & 33.87687 & 0.2062 & Accept $\mathrm{H}_{0}$ \\
\hline $\mathrm{r} \leq 2$ & 17.85365 & 27.58434 & 0.5073 & Accept $\mathrm{H}_{0}$ \\
\hline $\mathrm{r} \leq 3$ & 12.02901 & 21.13162 & 0.5448 & $\mathrm{Accept} \mathrm{H}_{0}$ \\
\hline $\mathrm{r} \leq 4$ & 6.950982 & 14.26460 & 0.4950 & Accept $\mathrm{H}_{0}$ \\
\hline $\mathrm{r} \leq 5$ & 2.631519 & 3.841466 & 0.1048 & Accept $\mathrm{H}_{0}$ \\
\hline
\end{tabular}

Source: Author's computation from E-view 7.0 
From the co integration results, the tables proved no co integrating equations among the variables. This means no long-run relationship that exists among the variables. This is contrary to the expectation of the results. It might be trace to effectiveness.

Table 7: Vector Error Correction Estimates

\begin{tabular}{|c|c|c|c|c|c|c|}
\hline Cointegrating Eq: & CointEq1 & CointEq2 & & & & \\
\hline Error Correction: & D(INFR) & $\mathrm{D}(\mathrm{CR})$ & $\mathrm{D}(\mathrm{DD})$ & $\mathrm{D}(\mathrm{TD})$ & $\mathrm{D}(\mathrm{SD})$ & $\mathrm{D}(\mathrm{NFA})$ \\
\hline R-squared & 0.368850 & 0.719086 & 0.648876 & 0.522421 & 0.592807 & 0.536203 \\
\hline Adj. R-squared & -0.183406 & 0.473287 & 0.341642 & 0.104539 & 0.236514 & 0.130380 \\
\hline Sum sq. resids & 5792.695 & 1988.201 & 105.8568 & 535.7865 & 714.5933 & 13579.08 \\
\hline S.E. equation & 19.02744 & 11.14731 & 2.572169 & 5.786765 & 6.682969 & 29.13232 \\
\hline F-statistic & 0.667898 & 2.925502 & 2.111996 & 1.250165 & 1.663817 & 1.321274 \\
\hline Log likelihood & -125.0578 & -108.4826 & -63.02265 & -88.15820 & -92.62185 & -138.2627 \\
\hline Akaike AIC & 9.035985 & 7.966617 & 5.033719 & 6.655368 & 6.943345 & 9.887917 \\
\hline Schwarz SC & 9.729849 & 8.660482 & 5.727584 & 7.349232 & 7.637210 & 10.58178 \\
\hline Mean dependent & 0.196774 & 0.051613 & 0.176774 & -0.149032 & -0.149355 & -0.258710 \\
\hline S.D. dependent & 17.49095 & 15.35972 & 3.170068 & 6.115227 & 7.648370 & 31.23996 \\
\hline \multicolumn{2}{|c|}{ Determinant resid covariance (dof adj.) } & $1.25 \mathrm{E}+10$ & & & & \\
\hline \multicolumn{2}{|c|}{ Determinant resid covariance } & $2.37 \mathrm{E}+08$ & & & & \\
\hline \multicolumn{2}{|c|}{ Log likelihood } & -562.8129 & & & & \\
\hline \multicolumn{2}{|c|}{ Akaike information criterion } & 42.89115 & & & & \\
\hline Schwarz criterion & & 47.60943 & & & & \\
\hline
\end{tabular}

The speed of adjustment of the variables is examined in the above table; the $\mathrm{R}^{2}$ of the variables indicates that the independent variables explained large variation of the dependent variables. This means the speed of adjustment is adequate.

5. Conclusion and Recommendations

This study examines the relationship between Money Supply and inflation in Nigeria, the independent variables comprises the components of Narrow and Broad Money Supply. The variables were sourced from publications. Findings revealed that Currency in Circulation, Demand Deposits, Savings Deposit have negative relationship with inflation rate while Net Foreign Assets and Savings Deposit have positive effect on inflation. The model summary shows that the independent variables can explain 75.5\%; the F-statistics proved that the model is significant. The study therefore conclude that money supply have significant relationship with Nigerian inflation rate. It therefore makes the following recommendations:

- The monetary authorities should device measures of managing the volume of money supply to avert its effect on inflation.

- The financial market and institutions such as the banking institutions should be reformed and its efficiency enhanced to absorb through savings the volume of money supplied by the monetary authorities.

- There is need to reform the savings rate to attract savings from the difference economic units and the monetary policy rate should be enhanced.

- Monetary authorities should integrate the objective of money supply with inflation control to enhance the effectiveness of monetary policy in achieving price stability.

References

Ajisafe, R. A., and Folorunso, B. A., (2002). The relative Effectiveness of Fiscal and Monetary Policy in Macroeconomic Management in Nigeria, African Economic and Business Review, 3 (1), 15 - 70.

Akinlo, A. E., (2003).The Determinants of Inflation in Nigeria, Indian Journal of Economics, LXXXVI (341).

Andrew, A., and Patrick, K., (2001). The Advantage of Transparent Instruments of Monetary Policy, Federal Reserve Bank of Minneapolis, Research Department Staff Report, 297,

Bernhardsen, T., and Holmsen, A., (2005). The choice of exchange rate assumption in the process of forecasting inflation, Staff Memo, 3, Central Bank of Norway.

Bleaney, M., (2000). Exchange Rate Regimes and Inflation Persistence, IMF Staff Papers, 247, $387-402$.

Bleaney, M., (2001). Exchange Rate Regimes and Inflation Persistence, IMF Staff Papers, 47 (3), 17 - 87. 
Brouwer, G., and N. R., (1998). Modelling Inflation in Australia, Forthcoming, Journal of Business and Economic Statistics.

Clemens, J. M. K., and Alex, L., (2002). Inflation Persistence under Semi-Fixed Exchange Rate Regimes: The European Evidence, 1974-1998

Debelle, G., and Galati, G., (2005). Current account adjustment and capital flows, BIS Working Papers, 169.

Elias C., and Joshua G., (2000). Monetary Growth and Exchange Rate Depreciation as Causes of Inflation in African Countries, International Monetary Fund, Washington, D.C., World Bank Working Paper.

Engle, R. F., and Granger, C. W. J., (1987). Co-Integration and Error-Correction: Representation, Estimation and Testing, Econometrica, 55 (6), 251-276. The dynamics of money supply, exchange rate and inflation in Nigeria Ed.

Ihor, D., (2001). Monetary Policy of Economic Growth in the Transitional Economy, Shevchenko National University, Kyiv, Ph.D Dissertation.

Iyabode M., (2000). New Perspectives on Inflation in Nigeria in Central Bank of Nigeria, CBN Economic and Financial Review, 38(2).

Johansen, S., (1988). Statistical Analysis of Cointegration Vectors, Journal of Economic Dynamics and Control, 7 (12), 231-254.

Mahamadu, B., and Phillip, A., (2003). Monetary Growth, Exchange Rates and Inflation in Ghana: An Error Correction Analysis, Working Paper, WP/BOG-2003/05,

Marta, M., Peter, S., and Anita, T., (2004). Inflation, Exchange Rates and the Role of Monetary policy in Albania, Working Paper, 6 (88), $89-97$.

Steven, B., Kamin, A., (1997). Multi-Country Comparison of the Linkages between Inflation and Exchange Rate Competitiveness, BIS Working Papers, 45, (9), 23 - 69.

\section{Copyrights}

Copyright for this article is retained by the author(s), with first publication rights granted to the journal.

This is an open-access article distributed under the terms and conditions of the Creative Commons Attribution license (http://creativecommons.org/licenses/by/4.0/). 